\title{
LIETUVOS KARIUOMENĖS KŪRĖJŲ SAVANORIŲ SĄJUNGOS KŪRIMAS
}

\author{
Aušra Jurevičiūtè
}

Lietuvos kariuomenès savanorių sajungos (ketvirtame dešimtmetyje pervadintos į Lietuvos kariuomenès kūrẻjų savanorių sajungą) steigimo idejją pirmą kartą iškẻlè savanoris M.Lazauskas 1925 m., minint Didžiojo Vilniaus Seimo 20 metų sukaktį ${ }^{1}$. 1926 m. balandžio 22 d. Šaulių sajungos žurnale "Trimitas" pasirodẻ straipsnelis "Savanorio laiškas", kuriame buvo rašoma: "...Visuomenejje kyla reikalas vèl ginti Lietuvą prieš naujus lenkų puolimus ir vaduoti mūsų Vilnių. Ar nereiktų mums savanoriams vèl susiorganizuoti, prisiminti savo pasišventimus ir perduoti juos jaunesnèms kartoms" ${ }^{2}$. Buvo siūloma organizuotis prie Šaulių sajungos. Šaulių sajungos vadovybè sutiko su tokiu siūlymu, bet kurti Savanoriu sajungą prie Šaulių sajungos nebuvo pradèta.

Staiga ir greitai Savanorių sajunga buvo kuriama daugiausia dèl to meto politinès Lietuvos situacijos po III Seimo rinkimų. Koalicinès vyriausybės darbai ir Seimo priimti ịstatymai kẻlè nerimą kariuomenejje, taip pat ir tarp savanoriu (dauguma to meto karininkų buvo savanoriai).To nerimo priežastys šios: 1) karo padèties atšaukimas, 2) politinių kaliniu amnestija, 3) pilietinių laisvių suteikimas, 4) svarstymai dèl kariuomenès sumažinimo bei karininkų algų apkarpymo (pvz., aviacijos karininkams buvo numatyta algas sumažinti iki 40 procentų $\left.{ }^{3}\right), 5$ ) kunigu algų klausimas ir kita. Opozicinės partijos - Krikščionių demokratų, Darbo federacija, Ūkininkų sajunga - ir toliau norejo būti valdžioje ir kūrè planus, kaip to pasiekti. Tautininkai, iš pradžių pritarę naujajai vyriausybei, tik po lapkričio 21d. studentų demonstracijos perẻjo ị opoziciją. Kadangi rinkimai buvo tik ką pasibaigę, ir parlamentiniu keliu patekti ị poziciją jos negalejjo, tad kritikavo kiekvieną Seimo sprendimą bei kairiosios vyriausybès žingsnị. Netgi 1926 m. rugsẻjo 28 d. sutarties tarp Lie-

\footnotetext{
${ }^{1}$ Savanoris.Kaunas. 1929.P.197.

${ }^{2}$ Savanorio laiškas// Trimitas. 1925.Nr.15 P.487.

${ }^{3}$ Kapsukas V. Buržuazinė Lietuva. V., 1961. P.59.
} 
tuvos ir SSSR pasirašymas kèlè didžiuli opozicijos nepasitenkinimą, nors ją pradejo rengti būdami valdžioje patys krikščionys demokratai.

1926 m. rugsėjo 5 d. trijose vietose vienu metu (Kaune, Šakiuose, Joniškyje) įvyko savanorių susirinkimai sajungos steigimo reikalu. Kaune susirinko 61 savanoris ị savanorių iniciatorių grupés pasitarimą. Susirinkimas nutaré, kad "yra reikalinga atskira savanorių organizacija dèl ekonominių, istorinių, kultūrinių bei tautinių motyvų, kad toji organizacija turi apimti visą Lietuvos plotą ir kartu sujungti visus savanorius ir kad tokios organizacijos centras turi būti Lietuvos sostinej su atskirais skyriais provincijoje" ${ }^{4}$. Buvo išrinkta ịstatų rengimo komisija: pirmininkas Girstautas, pavaduotojas - J.Kiaunis, sekretorius - M.Lazauskas, nariai - plk.P.Bizokas, L.Vailionis, L.Gira, K.Dineika, kandidatas - Girskis. Jie turejjo susisiekti su Šakių ir Joniškio savanoriais ir kartu per dvi savaites parengti įstatų projektą. Šakių savanorių suvažiavimas išrinko organizacinị komitetą, kurị sudaré: plk.V.Grigaliūnas-Glovackis (vẻliau - generolas), plk.ltn.P.Kaunas, Račiūnas, K.Matulevičius ir V.Jurgila5 ${ }^{5}$ Joniškyje susirinko 400 Lietuvos vasaros rytų partizanų ir savanorių, kurie taip pat pritarè sajungos kūrimo idėjai. Rugsèjo 9 d. buvo sušauktas Kauno ir Sakių organizacinių komitetų posėdis ir nutarta skubiai steigti sajungos skyrius apskrityse, kad būtų suspėta visuotinị suvažiavimą sušaukti lapkričio 23 dieną. Kadangi buvo žinių, jog vietose vyksta savanorių ginčai, buvo nutarta siųsti iš centro žmones, kurie aiškintų padètị šalyje ir kurtų sajungos skyrius.

Visi šie savanorių organizaciniai darbai sukèlè nemažą rezonansą spaudoje. Jau rugsẻjo 25 d. liaudininkų laikraštis "Lietuvos žinios" paskelbẻ straipsni "Kas yra tas savanorių globejjas p.Glovackis”, kuriame aprašė pulkininko atleidimo iš kariuomenès peripetijas, o rugsėjo $26 \mathrm{~d}$. straipsnyje "Kortas atidengus" buvo rašoma:"...Lietuva ne Italija ir savanoriai krikdemu politikos nevykdys" ". Rugsėjo 30 d. dabar jau laikraščio "Socialdemokratas" straipsnyje "Reakcija ruošiasi aktingai kovai" buvo aiškinama, kas kuria Savanorių sajungą ir kam ji reikalinga: ”...krikščionys demokratai bandydami įtraukti î partijų kovą pačią kariuomenę ...

\footnotetext{
${ }^{4}$ Protokolas savanorių iniciatyvinès grupės pasitarimo ịvykusio 1926 0905.//LCVA. F.560. Ap.1. B.103. P.37.

${ }^{5}$ Savanoris. Kaunas., 1929.P.200.

${ }^{6}$ Kas yra tas savanorių globejjas p.Glovackis // Lietuvos žinios. 1926m. rugsėjo 25d. Nr. 220.

${ }^{7}$ Kortas atidengus // Lietuvos žinios. 1926m. rugsėjo 26d. Nr. 221.
} 
gavo atlyžti, neradę joje jokio pritarimo savo sumanymams, tad klerikalų protas ima skubotai ieškoti sau naujų talkininkų, burti naujas jẻgas. Ta prasme ir kaipo vieną paskutiniųjų reakcijos bandymų tenka ịvertinti jų dabar iškeltą obalsį organizuoti savanorius" . Atsiliepdami į tokius straipsnius, Kauno, Šakių ir Panevėžio organizaciniai komitetai paskelbė: "...visi gandai, kad tveriamoji sajunga esanti kurios nors partijos padaras ir turinti kokius tai pasleptus tikslus, yra grynas prasimanymas" ${ }^{\text {. Kuriama }}$ savanorių sajunga kẻlẻ šiuos tikslus: kad ji turi būti nepolitinė, o jos nariai turi dirbti “...didžiausioje vienybẻje nepaisant jų politinių nusistatymų, kaip iki šiol tai yra, bet turint vieną tikslą: rūpintis savanorių ekonominiais bei kultūriniais reikalais, kelti jų tautišką supratimą, rinkti istorinės reikšmès medžiagą apie pirmus savanorių žygius kovose dèl Lietuvos nepriklausomybès, be to, paruošti juos kariniu atžvilgiu, dirbant šiuo atveju pilname kontakte su Šaulių ir Atsargos karininkų sajungomis"10.

Spaudos teiginiai, kad sajunga yra kokios nors partijos vaisius, sunkiai įrodomi. Galima tik numanyti, kam tai būtų paranku ir naudinga. Manau, jog savanorius vienijo tarp jų buvę aktyvūs ir labai patriotiškai nusiteikę karininkai ir eiliniai savanoriai. Tvirtinti galima tik tai, kad didžioji dalis savanorių buvo opozicija esamai tvarkai ir tai liudija kitų laikraščiu straipsniai. Laikraštis "Tautos valia" persispausdino "Darbininko atstovo" straipsnį, kuriame rašoma: "...nespejjo dar savanorių organizacija su budeliu Glovackiu, Gira ir Ko priešaky susiorganizuoti, kaip fašistai jau pradejjo veikti. Rugsejo $30 \mathrm{~d}$. nakti jie nuplèšė ir pavogè Panevėžio profsajungos iškabą. Jie taip pat veržèsi į būstinę, kuri yra miesto centre ir prie policijos posto. Yra gandų, kad padrąsẻję fašistai rengiasi užpulti profsajungą"11. Kad panašūs savanorių veiksmai vyko, pavirtina ir Panevėžio skyriaus organizacinio komiteto priimtas nutarimas. Jame sakoma: "dẻl komunistų mitingo spalio 2 d. nutarta daugiau suorganizuoti savanorių ir trukdyti komunistams mitinguoti ${ }^{12}$ ". Ne tik kairioji spauda savanorius vadina fašistais. "Lietuvos žinios" spalio 8 d. rašè: "Glovackių ir kitų tikslus net ramus A.Smetona "Lietuvy" apibūdino kaipo fašis-

\footnotetext{
${ }^{8}$ Reakcija ruošiasi aktingai kovai . // Socialdemokratas.1926m. rugsejo 30d. Nr.39.

${ }^{9}$ Raštas savanorių organizacijos reikalu // LCVA. F.560. Ap.1. B.189. P.20-21.

${ }^{10}$ Ten pat.

${ }^{11}$ Vedamasis. //Tautos valia. 1926m. spalio 31d. Nr.2 .P.2., Fašistų darbai. //Darbininkų Atstovas. 1926m.spalio 23d. Nr.23.

${ }^{12}$ LCVA. F.560. Ap.1. B.254. P.2.
} 
tinius, vedančius kraštą prie naminio karo"13 . Taip buvo rašoma spalio pradžioje, o lapkričio 7 d. A.Smetona Kauno apskrities savanorių organizacinių komitetų suvažiavime buvo išrinktas garbès pirmininku ir vis buvo kviečiamas ị susirinkimus. I vieną iš organizacinių susirinkimų buvo numatyta pakviesti ne tik A.Merki, bet ir A.Smetoną, norèta "aptarti svarbius juridinio pobūdžio klausimus", bet, deja, nė viename jų A.Smetona nedalyvavo ${ }^{14}$.

1926m. spalio 23 d. pasirodè naujas laikraštis "Tautos valia". Tai buvo savaitinis politikos ir literatūros laikraštis, kurio tikslas - "suspiesti i būrị visus tuos, kurie brangina Lietuvą labiau negu nudèvetas doktrinas..."15 Šị laikraštị redagavo savanoris kūrëjas 2-ojo péstininkų pulko organizatorius ir pirmas jo vadas plk.Vincas Grigaliūnas-Glovackis ir savanoris kūrèjas mjr.J.Tomkus. Laikraštyje daug raše kpt.Klimaitis. Pirmojo numerio vedamajame buvo rašoma: "Šiandien diskutuojame dẻl savanorių sajungos tikslų, kai niekas iš "tikrosios demokratijos" eilių neišdrịsta išsižioti dèl viešai veikiančių bolševikų organizacijų"16. "Tautos valia" kvietè susirinkti "senają gvardiją" ir savo šeimoje pasvarstyti, ką reikia daryti, kai Tévynei gresia pavojus: "Bolševikiškieji "Darbininku atstovai”, visokios profsajungos ir komječeikos ruošia tẻvynei kruviną galą.

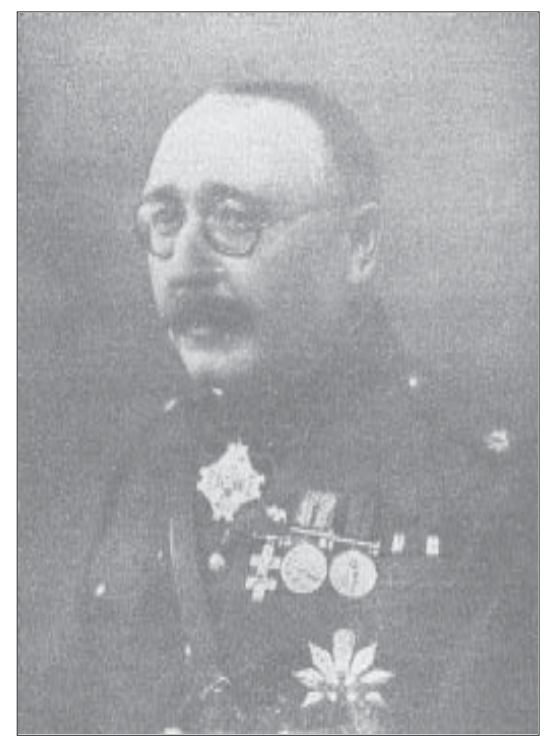

Gen.ltn. Vincas Grigaliūnas-Glovackis, 2 pesstininku pulko organizatorius ir pirmas jo vadas, "Tautos valios" redaktorius

\section{Pilsudskis vèl taikstosi smogti peiliu}

Lietuvos nepriklausomybei. Gedimino pilis pléšriųjų vanagų naguose te-

\footnotetext{
${ }^{13}$ Kas mulkina savanorius ir demoralizuoja kariuomenę // Lietuvos žinios.1926m. spalio 8d. Nr.231. P.

${ }^{14}$ LKS organizacinio komiteto Centro valdybos protokolas. Nr.3. 1926m. lapkričio 14d.// LCVA.F.560. Ap.1. B.191. P.5.

${ }^{15}$ Vedamasis // Tautos valia. 1926m. spalio 23d. Nr. 1.

${ }^{16}$ Ten pat.
} 
besikankina. Senosios gvardijos darbai nenudirbti. Dèl to ji šiandien telkiasi krūvon, steigia Savanorių sajungą, kad savoje šeimoje apsvarsčius kas reikia daryti. Savanorių širdys nujaučia Tẻvynei gresiantị pavojų. Kyla Lietuvos milžinų gvardija.Vyrs ị vyrą, šimtų - šimtai telkiasi jie savo sajungon. Skersai kelio jiems gali stoti tik tie, kam Lietuvos gerovė ir laisvè nerūpi”"17.

Ši citata aiškiai apibūdina tikruosius Savanorių sajungos kūrimo tikslus. Plk.V.Grigaliūno-Glovackio ir kitu savanorių mintis apie sajungos būtinumą palaikè ir krikščionys demokratai. Darbo federacijos frakcija Seime pateike įstatymo projektą, kuris numatẻ buvusiems savanoriams leisti nemokamai važiuoti Lietuvos geležinkeliais, jei jie važiuos organizacijos reikalu. Prie to projekto buvo pridètas tokio turinio raštas: "...vèl niaukias Tévynès dangus, iš oro ir viduje priešai rengia Lietuvos Nepriklausomybės mirtị... nepaprastu greitumu savanoriai susibūrẻ ị organizuotas eiles, kad būdèti...Tèvynès laisvės sargyboje"18. Galima teigti, kad kuriama Savanoriu sajunga buvo remiama krikščionių demokratų, bet, kaip rašo laikraštis "Socialdemokratas”, “...lietuviškajji fašizmą sukūrè nusibankrutijęs kademų blokas. ...Bet nauja dar kas, kad ir mūsų tautininkai fašizmo nesibaido. Raseiniuose š.m. rugsejjo 19d. tautininku valdybos narys advokatas Noreika savo paskaitoj išsireiškė, kad Lietuvai gresia bolševizmo pavojus. Jam pašalinti reikia veikti Italijos pavyzdžiu, kur "sveikas visuomenès elementas"susiorganizavo ị fašistų organizaciją ir tą pavojų pašalino. Taigi ir Lietuvoj reikia "sveikam elementui" organizuotis ir nebūtinai ị pačiu fašistų organizaciją (gal ị kademų proteguojamus "savanorių būrius") ...Todèl valdžiai reikia ypač susirūpinti ir minètas "savanoriụ" organizacijas labiau kontroliuoti, kitaip vèl pasijusime po kieta "troicès"(troicè - krikščionys demokratai, Ükininkų sajunga, Darbo federacija) ranka" 19 .

kuriama Savanorių sajunga buvo skelbiama esanti apolitinè, bet jos sprendimai ir darbai rodè ką kitą. LKS organizacinio komiteto centro valdyba aštriai reaguodavo ị kiekvieną komunistų išsišokimą ir Vyriausybès priimamus sprendimus, kurie, jų manymu, buvo nenaudingi Lietuvai. Lapkričio 7 d. posédyje buvo priimti nutarimai dẻl lenkų užgrob-

\footnotetext{
${ }^{17}$ Senoji gvardija // Tautos valia. 1926m. spalio 23d. Nr.1.

18 Tautos valia. $1926 \mathrm{~m}$. lapkričio Nr.3.P.4.

${ }^{19}$ Fačistai nori praryti Lietuv ${ }^{1} / /$ Socialdemokratas. 1926m. spalio 14d. nr.41.
} 
tose teritorijose uždarinėjamų lietuviškų mokyklų, taip pat Lietuvoje steigiamų lenkų mokyklų ir kad savanoriai ne dẻl to kovojo ${ }^{20}$.

Lapkričio $11 \mathrm{~d}$. LKSS paskelbẻ rezoliuciją, kurią įteikẻ Ministrui Pirmininkui ir spaudai. Joje buvo rašoma: "Savanorių organizacinè CV, pildydama savanorių organizacinių komitetų suvažiavimo nutarimą, turi garbės atkreipti vyriausybės dẻmesị ị sekantị: 1918-1919 m. geriausi Lietuvos sūnūs išgirdo lietuvių tautos šaukimą ir stojo ị garbingas kariuomenès eiles Lietuvą ginti. Lietuvos savanoriai garbingai ir sėkmingai atliko savo užduotị ir realizavo daugelio metų Lietuvos sūnų - žadintojų svajonę - atstatyti Nepriklausomą Lietuvą. Gerbdami žuvusių už Lietuvos laisvę atmintị, savanoriai negali nutylèti apie tuos liūdnus faktus, kurie pasireiškia dabartiniu metu Nepriklausomoje Lietuvoje. 1) Š.m. lapkričio 7 d. svetimas Lietuvai komunistinis gaivalas, tyčiodamasis iš mūsų tautos idealų, iškabino Kaune ịvairiose vietose vẻliavas, kurių kruviname fone ịstate Lenino, rusų ir visų tautų laisvės smaugejo, paveikslą. 2) Lietuvos vyriausybé, nepaisant persekiojimų ir uždarymų lietuvių mokyklų mūsų amžinų priešų lenkų okupuotoje Lietuvoje, atidaro ir remia lenkiškas mokyklas kai kur net tose vietose, kur atidarytoji lenkiškoji mokykla turi tikslo ne šviesti, bet ištautinti lietuviškai kalbančiu šeimynų vaikus. Pažymėti reiškiniai kenkia lietuvių tautos dvasiai, Lietuvos Nepriklausomybės ideologijai. Mes, savanorių atstovai, su širdgėla primename vyriausybei, kad tokie apsireiškimai kraštui yra labai pavojingi, pražūtingi Lietuvos nepriklausomybei, dẻl kurios savanoriai yra kovoję"21.

Visi šie nutarimai buvo siunčiami vyriausybei ir laukiama jos reakcijos. Kadangi vyriausybė nereagavo, savanoriai ėmėsi kitokių veiksmų savo nepasitenkinimui išreikšti. Jie energingai ịsijungė ị studentų organizuojamą demonstraciją. Tuo metu universitete mokèsi nemažai savanorių, kurie buvo aktyvūs lapkričio $21 \mathrm{~d}$. demonstracijos organizatoriai ir dalyviai. Tai plk.V.Grigaliūnas-Glovackis, mjr.J.Tomkus, mjr.J.Petruitis, Algirdas Sliesoraitis, kuris buvo LKS CV iždininkas ir korporacijos "NeoLithuania" pirmininkas. Šią demonstraciją rengè studentai ateitininkai ir neolituanai. Laikraščiai "Tautos valia" ir "Rytas" specialiais skelbimais kvietė žmones ị politinị mitingą bei demonstraciją prieš vyriausybę.

Lapkričio $21 \mathrm{~d}$. demonstracija buvo vaikoma gausiomis raitosios ir pėsčiosios policijos pajėgomis ir tai sukèlè didžiuli visuomenès nepasi-

${ }^{20}$ LKS Organizacinio komiteto CV protokolas. 1926m. lapkričio 7d. // LCVA. F.560. Ap.1. B.191. P.1-2.

${ }^{21}$ LKSS Organizacinio komiteto CV protokolas. 1926m. lapkričio 17d. // Ten pat. P.4. 


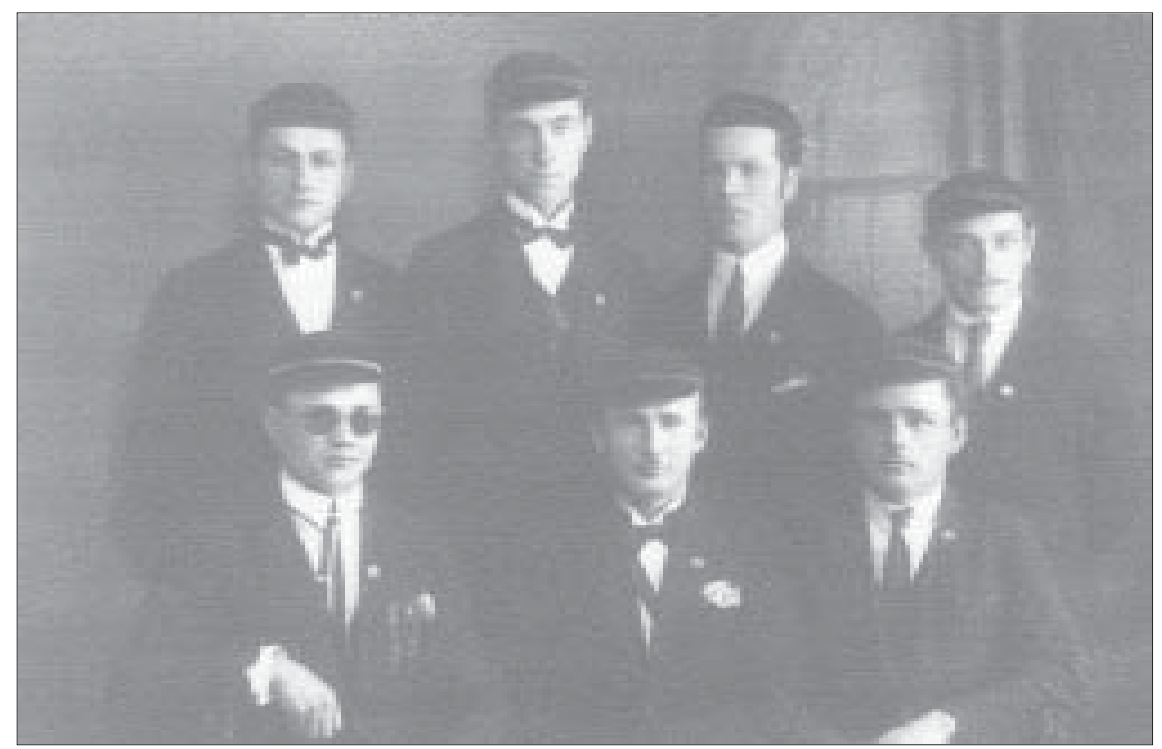

$1927 \mathrm{~m}$. vasario $16 \mathrm{~d}$. Lietuvos universiteto studentai savanoriai:

1-as iš kairès J. Karutis - 2 Vyčio kryžių kavalierius, 2-as J. Kiaunis, 3-as A. Koncė, stovi J. Vaitkevičius, A. Rukša, nežinomas, J. Andriūnas.

tenkinimą vyriausybės veiksmais. Savanoriai sureagavo žaibiškai. Lapkričio 22 d. LKSS organizacinio komiteto Centro valdyba, kurią sudare pirmininkas ats.plk.ltn.Zubrys, nariai - K.Matulevičius, A.Sliesoraitis, J.Elisonas, J.Kiaunis, K.Bieliūnas ir J.Pautienius, prièmé protestą. Jame buvo rašoma: "...kuomet vyriausybe i savanorių protestą nerado reikalo atkreipti dėmesio, š.m. lapkričio $21 \mathrm{~d}$. valstybiniai ir tautiniai nusistačiusioji Lietuvos universiteto studentija, kurios tarpe randasi daug karių-savanorių, mėgino dar kartą priminti vyriausybei ir visuomenei, kad panašūs reiškiniai yra žalingi ir pražūtingi mūsų nepriklausomybei - vyriausybė, paneigdama studentiją, kartu ir mūsų savanorių idealus, pavartojo niekur nepateisinamas brutalias pajėgas, smurtą ir išniekino mūsų tautos šventovę Karo muziejų"22 .

Savanorių dalyvavimą demonstracijoje patvirtina ne tik tai, bet ir straipsnis oficioze "Lietuva":"...fašistinių demonstracijų, organizacijų, organizuojamų savanorių, ir kurstymų i sukilimus tikslas yra ne krašto tvarka, jo gerové, bet anarchija, netvarka, griežtas pasiryžimas neleisti Sei-

${ }^{22}$ LKSS Organizacinio komiteto CV protokolas. 1926m. lapkričio 22d. // Ten pat. P.9. 
mui dirbti”23 . Aukščiau išdèstyti faktai leidžia daryti prielaidą, kad savanoriai, buriami ị Savanorių sajungą, turèjo sudaryti patikimą jẻgą, kuria galima būtų pasiremti ruošiamame gruodžio 17 d. perversme. Karininkai, kurie kūrẻ LKSS, - plk. V.Grigaliūnas-Glovackis, J.Kiaunis, K.Matulevičius, mjr.A.Merkys, A.Sliesoraitis, mjr.J.Tomkus, gen.V.Nagius-Nagevičius, kpt.Klimaitis ir kt., buvo perversmo organizatoriai ir vykdytojai. Slaptosios karininku sajungos valdyboje $1926 \mathrm{~m}$. buvo taip pat visi savanoriai mjr.I.Slapšys, pirmininkas gen.št.plk.V.Skorupskis, kpt.A.Mačiuika (19391940m. buvęs LKKSS pirmininku), kpt.J.Matulevičius, kpt.A.Steponaitis ${ }^{24}$. Faktą, kad kuriama Savanorių sajunga žinojo apie perversmą ir jos nariai jame dalyvavo, patvirtina ir dokumentai. 1926 m. gruodžio 19 d. buvo numatytas Kauno apskrities organizacinių komitetų suvažiavimas, bet dẻl mažo savanorių skaičiaus negalejo prasidėti. Visi kažko laukẻ (tuo metu kaip tik vyko Nepaprastoji Seimo sesija, kurioje turèjo būti išrinktas Prezidentas).Valdybos protokole buvo rašoma: "... tuo metu atvyko karininkas ir pranešè, kad Seimas išrinko A.Smetoną prezidentu. Sliesoraitis dẻkoja kariuomenei už valstybės išgelbejimą iš bolševikų ir lenkų pavojaus..." 25

Suvažiavimas buvo atidètas iki $1927 \mathrm{~m}$. sausio $2 \mathrm{~d}$. Tokie susirinkimai gruodžio 19d. vyko ne tik Kaune, bet ir Marijampoleje, Seinuose, Vilkaviškyje. Visuose juose buvo sveikinama kariuomenè ir priimtos rezoliucijos naujai Vyriausybei palaikyti: "Iš savo pusès pasižadame, esant reikalui ir tamstoms pašaukus, stoti su ginklu rankose ginti krašto nepriklausomybès nuo vidaus ir išorés priešų"26. Savanorių dalyvavimo perversme ir Savanorių sajungos reikejjo paremti ir užtikrinti pagalbai vietose. Tai patvirtina ir gen. V.Grigaliūno-Glovackio atsiminimai, kur jis rašo, kad 1926 m. “...jau visa Lietuva sukelta ir sukilimas baigiamas ruošti”27.

1927 m. sausio 8-9 d. įvyko Savanorių sajungos steigiamasis suvažiavimas, kuriame dalyvavo prezidentas A.Smetona, mjr.A.Merkys, gen.V.Nagius-Nagevičius, plk.J.Čaplikas, gen.S.Žukauskas, plk.P.Plechavičius, mjr.I.Motiejūnas-Valevičius. Suvažiavime buvo priimti sajungos ịstatai, iškelti jos tikslai: saugoti ir ginti Lietuvos laisvę ir nepriklausomybę; kelti ir ugdyti tautišką lietuvių sąmonę; gerinti savo narių ir žuvusiųjų savanorių šeimų ekonomišką būklę; rūpintis Lietuvos karžygių atminimo gerbimu ${ }^{28}$.

\footnotetext{
${ }^{23}$ Dvi tiesos. // Lietuva. 1926m. lapkričio 27d. Nr.269.

${ }^{24}$ Gen.Povilas Plechavičius. Brooklyn., 1978.P.35.

${ }^{25}$ LKSS Kauno skyriaus protokolai. // LCVA. F.560.Ap.1. B.2. P.21.

${ }^{26}$ Ten pat. P.63.

${ }^{27}$ Liudininkai kalba. // "Lietuvių dienos". Los Angeles., 1956. Nr.10. P.6.

${ }^{28}$ LKSS suvažiavimo protokolas. 1927m. sausio 8-9d. // LCVA. F. 560. Ap. 1. B.3. P.290. 
Lietuvos kariuomenės savanorių sajungos kūrimo darbai buvo baigti. Prasidejo kasdieninis darbas, kuris po audringos pradžios nebuvo aktyvus. Po truputi buvo kuriami skyriai vietose. Didesnis sajungos veiklos paki-

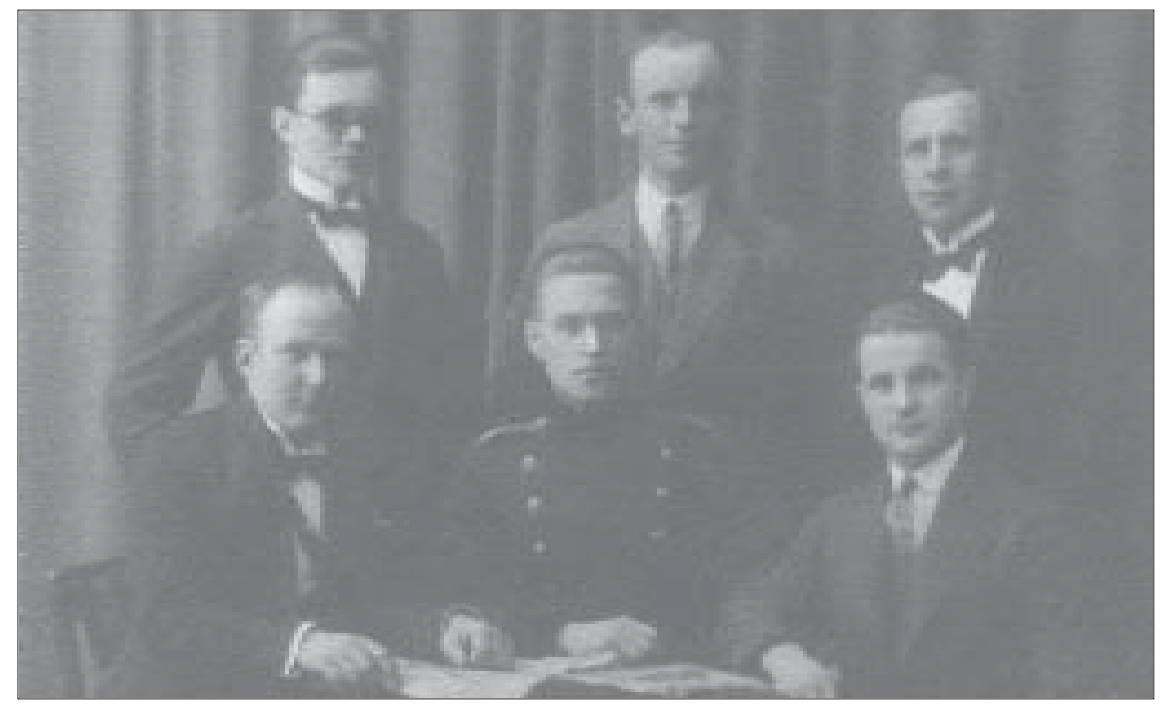

LK SS centro valdyba 1928-1929 m. Sėdi iš kairès: 1-as Jurgis Kiaunis - vicepirmininkas, 2-as Kazys Matuliavičius - vicepirmininkas, 3-as Vitas Statkus - vicepirmininkas, stovi: 1-as Jonas Karutis - sekretorius, 2-as Juozas Maliušis - iždininkas, 3-as Stasys Butkus - sekretorius.

limas buvo susijęs su 1929-1930m. Tai sąlygojo Augustino Voldemaro pašalinimas iš Ministro Pirmininko pareigų ir "Geležinio vilko" organizacijos pertvarkymas. Šiai organizacijai priklausẻ nemažai aktyvių savanorių. Tuo metu buvo suimti 8 savanoriu sajungos ir net 3 Centro valdybos nariai - A.Sliesoraitis, K.Matulevišius, J.Karutis. Jiems nebuvo pateikti jokie kaltinimai.

Remiantis aukščiau išdèstytais faktais, galima daryti prielaidą, kad savanoriai beveik visada buvo esamos valdžios opozicija. Be jų neįvyko né vienas pasipriešinimo aktas, išskyrus tuos, kuriuos rengẻ komunistai. To priežastis, manau, buvo jų didžiulè meilè savo Tẻvynei ir nuoširdus tautinis jausmas, tautos interesus iškeliant aukščiau savưjų. 